UDC 544.252.234+537.226.4

E. P. Pozhidaev, S. I. Torgova, V. V. Kesaev, V. A. Barbashov

\title{
FERROELECTRIC LIQUID CRYSTAL MATERIAL WITH LOW BIREFRIGENCE
}

\author{
P. N. Lebedev Physical Institute, 53 Leninsky Pr., Moscow, 119991, Russia \\ E-mail: epozhidaev@mail.ru
}

Ferroelectric liquid crystal (FLC) mixture with a low birefringence index $(\Delta n \leq 0.1)$ is developed. It consists of a three-component achiral matrix, which contains two phenacyl esters and one Demus ester, and a phenylpyrimidine derivative is used as a chiral dopant. The ferroelectric smectic $C *$ phase of the mixture exists in the temperature range from $18^{\circ} \mathrm{C}$ to $53^{\circ} \mathrm{C}$. This mixture allows reducing of chromatic aberrations of ferroelectric liquid crystal cells because of a weaker birefringence dispersion compared with the known ferroelectric liquid crystals. The manufacturing technology of the electrooptical half-wave light modulators based on the developed mixture is much simpler than with the known FLCs, since the required thickness of the liquid crystal layer is inversely proportional to the birefringence magnitude.

Key words: ferroelectric liquid crystal, phenacyl esters, Demus ester, birefringence index.

DOI: 10.18083/LCAppl.2018.2.31

\section{Е. П. Пожидаев, С. И. Торгова, В. В. Кесаев, В. А. Барбашов}

\section{СЕГНЕТОЭЛЕКТРИЧЕСКИЙ ЖИДКОКРИСТАЛЛИЧЕСКИЙ МАТЕРИАЛ С НИЗКИМ ДВУЛУЧЕПРЕЛОМЛЕНИЕМ}

\author{
Физический институт им. П. Н. Лебедева, Ленинский пр., 53, 119991 Москва, Россия \\ E-mail: epozhidaev@mail.ru
}

Разработана сегнетоэлектрическая жидкокристаллическая четырехкомпонентная смесь с низким показателем двулучепреломления $(\Delta n \leq 0,1)$, состоящая из трехкомпонентной ахиральной матрищы, $в$ состав которой входят два фенащиловых эфира и эфир Демуса, а в качестве хиральной добавки используется одно из производных фенилпиримидина. Сегнетоэлектрическая смектическая $C^{*}$ фаза смеси существует в температурном интервале от $18{ }^{\circ} \mathrm{C}$ до $53{ }^{\circ} \mathrm{C}$. Эта смесь позволяет понизить хроматические аберрачии в сегнетоэлектрических жидкокристаллических ячейках вследствие более слабой дисперсии двулучепреломления, чем у известных до сих пор сегнетоэлектрических жидких кристаллов (СЖК). Технология изготовления электрооптических полуволновых модуляторов света на основе разработанной смеси гораздо проще, чем на основе известных СЖК, поскольку необходимая толщина слоя жидкого кристалла обратно пропорииональна величине двулучепреломления.

Ключевые слова: сегнетоэлектрические жидкие кристалль, фенациловые эфиры, эфир Демуса, показатель двулучепреломления.

\footnotetext{
(C) Pozhidaev E. P., Torgova S. I., Kesaev V. V., Barbashov V. A., 2018
} 


\section{Introduction}

Nematic liquid crystal (NLC) materials with low birefringence $(\Delta n \sim 0.05-0.1)$ have been used in activematrix displays since 1984 [1]. The point is that with decreasing of birefringence, a reduction in the chromatic aberrations of the NLC based electro-optical cells has been achieved [2-5]. The derivatives of cyclohexyl-cyclohexanes, perfluorinated derivatives of aromatic compounds and derivatives of trans-1,3dioxanes are usually used as components of NLC materials with low birefringence [3].

However, there are no ferroelectric liquid crystals within the listed classes of chemical compounds, and therefore the physico-chemical principles of the birefringence diminishing, which have been justified for NLCs, hardly can be applied to FLCs. And, as a matter of fact, the development of the original physical and chemical basics of materials science of the low birefringent $(\Delta n \leq 0.1)$ FLCs has already begun recently, since FLCs provide two or three orders of magnitude faster response time compared with NLCs. Up to now only few articles has been published concerning the creation of FLCs with a low birefringence $[6,7]$.

The FLC mixture with $\Delta n=0.062$ [6] has been developed at mixing of an achiral smectic matrix and a chiral dopant. Achiral compounds are based on phenylpyrimidine core with a trisiloxane terminated decyloxy chain on one side and the alkoxy chain on the opposite side. The chiral dopant is a similar compound, just with chiral alkoxy chain on the opposite side. Disadvantages of this mixture such as low spontaneous polarization $P_{s}=2.5 \mathrm{nC} / \mathrm{cm}^{2}$ and a very small tilt angle $\theta$ of molecules in smectic layers $(\theta \cong 3 \mathrm{deg})$ hardly allow to use it in electro-optical modulators.

The thing is that the light transmittance $T$ of FLC cells placed between crossed polarizers is defined, as it was proven in [7], by the relationship:

$$
T=\sin ^{2} 4 \theta \cdot \sin ^{2} \frac{\pi\left(n_{e}-n_{o}\right) d}{\lambda},
$$

where $n_{e}$ and $n_{o}$ are extraordinary and ordinary refractive indices, respectively, $d$ is the FLC layer thickness, and $\lambda$ is the wavelength of the incident light. The maximum transmittance of the structure, according to (1), is achieved at $\theta=22.5^{\circ}$, and with some critical thickness of the FLC layer:

$$
d_{\lambda / 2}=\frac{\lambda}{2 \Delta n},
$$

which is called as the thickness of half-wave FLC plate. Here, in (2), $\Delta n=n_{e}-n_{o}$ is the birefringence index.

Obviously, at $\theta=3^{\circ} T \leq 4.3 \%$ with any $d$ and $\lambda$, as it follows from (1). It is difficult to expect that an electrooptical modulator with such a low light transmittance can be useful in electro-optical devices.

The same problem with low light transmittance arose when the authors [8] have developed a method for obtaining a negative dispersion of the refractive index for a material consisting of smectic layers and monomeric molecules. As the FLC matrix the authors used the commercially avaliable mixture FELIX 015100 (Clariant), and as a dopant, a mixture of reactive monomers triallyl-1,3,5-triazine-2,4,6 and 1,6hexanediol diacrylate. As a by-product result, they obtained the FLC material with $\Delta n \approx 0.06$, however, the spontaneous polarization of the mixture did not exceed $2.5 \mathrm{nC} / \mathrm{cm}^{2}$, and $\theta \cong 2.5 \mathrm{deg}$.

Evidently, so small spontaneous polarization results in protracted response time, which invalidates advantages of ferroelectric liquid crystals compared with NLCs. Moreover, very small tilt angle $\theta \cong 2.5^{\circ}-$ $3^{\circ}$ of known $[6,8]$ low birefringent FLC mixtures makes unreasonable their applications in commercial photonic devices because of mentioned above low light transmittance problem.

In our work we describe one of the possible approaches to elaboration of ferroelectric liquid crystals with the low birefringence, the tilt angle $\theta$, which is close to 22.5 degree, thereby ensuring an opportunity of maximal light transmittance according to (1) and with sufficiently high spontaneous polarization $P_{s}$. In addition, we will try to provide an acceptable value for the rotational viscosity $\gamma_{\varphi}$ in order to achieve minimization of the electro-optical response time $\tau$, in accordance with the relation (3) given, for instance, in [7].

$$
\tau \sim \gamma_{\varphi} / P_{s} E,
$$

where $E$ is the electric field tension.

Typically, the birefringence of the FLCs is between 0.15 and 0.25 [9], therefore, in order to satisfy condition (2) at a wavelength of $540 \mathrm{~nm}$ (maximal spectral sensitivity of the human eye), the thickness of the half-wave FLC layer in the electro-optical cells should be from 1.0 to $1.7 \mu \mathrm{m}$. The fabrication of electro-optical cells with such a small thickness of the FLC layer is quite difficult task since dust particles up to $2.5 \mu \mathrm{m}$ size always exist in the air as a result of Brownian motion. 
The most significant purpose of our work is to achieve a situation when the thickness of the half-wave FLC plate due to the birefringence lowering will exceed (according to ratio (2)) the maximal size of dust particles that are permanently in the air. This will greatly simplify the FLC cells manufacturing technology, because dust particles that can penetrate accidentally into the gap between the cells substrates can not violate the uniformity of the gap and create an electrical contact between the substrates of the cells.

\section{Approach to elaboration of the low birefringent mixtures}

The simplest, the cheapest and the most effective method for obtaining of FLC mixtures with desired properties is the admixing of the chiral compound to the achiral smectic $\mathrm{C}(\mathrm{SmC})$ matrix [10]. The first step is development an achiral SmC matrix that has the required properties, such as a phase transitions sequence, rotational viscosity and the proper $\theta$ angle. The second stage consists in choosing a chiral dopant that provides the required values of the spontaneous polarization and the helix pitch [10]. In some cases, chiral compounds, even being non-mesogenic, expand the temperature range of the $\mathrm{SmC}^{*}$ phase of the mixture, or even induce it from the nematic matrix [11]. At the same time, a high concentration of chiral nonmesogenic dopants in the mixture leads to suppression of the smectic $\mathrm{C}^{*}$ phase [12].

The same principles of FLC mixtures creation mentioned above were also used in this work, with only one limitation: all components of the mixtures should have low birefringence. It was assumed that the birefringence of the mixture would be approximately proportional to the molar fraction of each component.

The birefringence of liquid crystals is determined by their polarizability, which depends on the length of the electronic chains of conjugation. The problem of choosing of components with low birefringence is reduced to the choice of compounds with saturated bonds in the central fragments of molecules, other words, to replacement of aromatic rings by the cyclohexane ones or interruption of the conjugation chains by introducing aliphatic spacers. Nowadays, the absolute majority of known smectics compounds have $\Delta n>0.14$ [13]. In the database LiqCryst 5.1 among 14260 smectics 1506 compounds containing at least one saturated ring were found but only one compound containing exclusively aliphatic units without aromatic rings [14]. This single compound demonstrates only smectic E phase, which is difficult to use because of very high viscosity. The $\mathrm{SmC}$ phase was found in wholly aliphatic compounds, namely in the mixtures of two steroids [15], however, in narrow ranges of component concentrations and of phase existence temperatures. Therefore, it is hardly possible to use of steroids to create FLC with low birefringence.

The birefringence index of LC molecules containing two conjugated aromatic rings is usually about 0.15 , while the non-conjugated single aromatic ring corresponds to $\Delta n$ in the range 0.07-0.08. Therefore, in order to obtain FLC mixtures with a low $\Delta n$, components consisting of two or more conjugated aromatic or heteroaromatic rings should be excluded.

Phenacyl esters of cyclohexanecarboxylic acids $(\mathrm{PhE})$, which have been first described in [16] could be promising as compounds for preparation of the low birefringent FLC mixtures. This class of $\mathrm{LC}$ has a wide range of SmC phase starting from $60-70{ }^{\circ} \mathrm{C}$ till $100^{\circ} \mathrm{C}$, while $\Delta n$ of cyclohexane containing phenacyl ester does not exceed 0.1 .

In addition to phenacyl esters, we have chosen the ester of trans-4-butylcyclohexanecarboxylic acid and $p$-ethoxyphenol, which is also known as Demus ester [17]. This compound has only a nematic phase in a wide range of temperatures, and $\Delta n \sim 0.07-0.08$. With the selection of components mentioned above, the problem was to suppress the nematic and to induce the $\mathrm{SmC}$ phase in the mixtures over a wide temperature range, while preserving low birefringence.

\section{Techniques for preparation and investigations of FLC cells}

The FLC cells with homogeneous planar alignment were fabricated using rubbed polyimide PMDA-ODA [18, 19] as aligning layers that cover indium tin oxide (ITO) layers deposited onto glass substrates. The cell gap of assembled experimental cells was formed with glassy spacers and then fixed by epoxy glue. The cells were filled with FLCs in isotropic phase by capillary action.

The phase transition temperatures were determined using differential scanning calorimetry (DSC) and polarization microscopy (POM), which also allows doing micro-photos of liquid crystal textures. For this purpose a polarizing microscope POLAM-P312 was used. Refractive indices $n_{o}$ and $n_{e}$ were measured at wavelength $\lambda=589.3 \mathrm{~nm}$ by Abbe 
refractometer, while the birefringence dispersion $\Delta n(\lambda)$ was calculated through measured (by Ocean Optics spectrometer) light transmittance spectrum of the FLC cells placed between crossed polarizers.

Spontaneous polarization $\boldsymbol{P}_{\boldsymbol{s}}$ was measured using the field-reversal method [20], and rotational viscosity $\gamma_{\varphi}$ was obtained from measurements of the electrooptical response time and $\boldsymbol{P}_{\boldsymbol{s}}$, as it has been grounded in [21].

\section{Development of the low birefringent mixture}

As an achiral matrix, three-component mixture consisting of two phenacyl esters (I) and (II) and Demus ester (III) was developed:

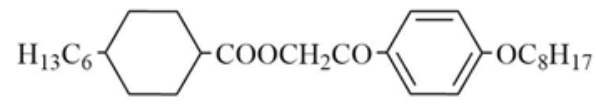

(I)

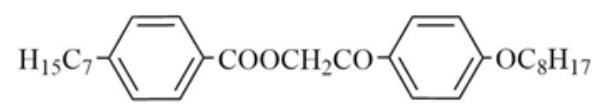

(II)

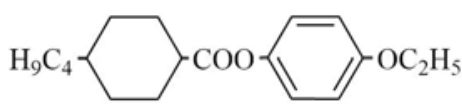

(III)

The 5-(2-fluorooctyloxy)-2-[2-fluoro-4-(nonyloxy) phenyl]pyrimidine (IV) [22] was used as a chiral dopant to obtain the desired values of the spontaneous polarization and helix pitch.<smiles>CCOc1ccc(-c2ncc(OCC(C)(F)F)cn2)c(F)c1</smiles>

(IV)

Binary mixtures of Demus ester (III) and phenacyl ester (I) have been studied, and the phase diagram of the mixtures was plotted (Fig. 1). The task of these experiments was to find the eutectic mixture of the compounds mentioned above. For each mixture, refractive indices $n_{o}$ and $n_{e}$ were measured at the wavelength of $589.3 \mathrm{~nm}$. The disadvantage of phenacyl ester (I) is the presence of the orthogonal smectic B phase ( $\mathrm{SmB})$, see Fig. 1. The $\mathrm{SmB}$ phase is not electrooptical, and therefore it was necessary to suppress it, what was achieved in the eutectic mixture of the components. Note, that $\Delta n$ of the eutectic mixture is equal to 0.092 .

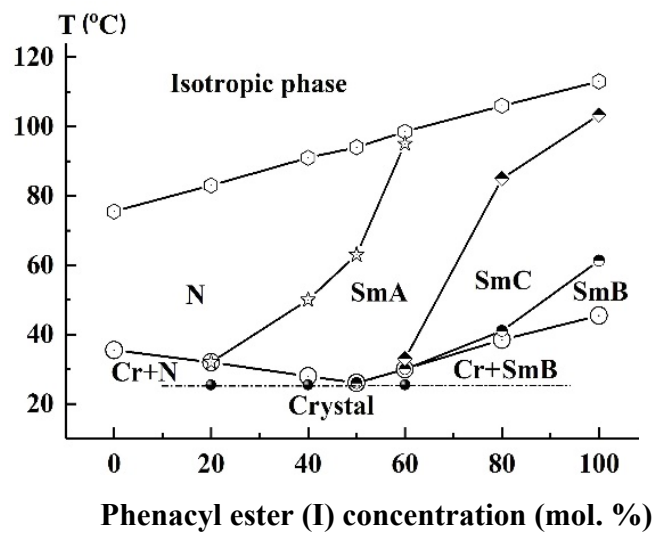

Fig. 1. The phase diagram of the binary mixture of Demus ester (III) and phenacyl ester (I)

However, the SmC phase is not observed in the eutectic mixture. The phenacyl ester (II) was added to the eutectic mixture to induce the $\mathrm{SmC}$ phase. Further, a chiral fluorine-containing phenylpyrimidine (IV) was added to the resulting three-component mixture as the chiral dopant. Thus, a four-component FLC mixture LDN-13 with $\Delta n \cong 0.097$ at $\lambda=589.3 \mathrm{~nm}$ was developed. Phase transitions sequence of the mixture at heating from preliminary obtained solid crystalline state is the next: $\mathrm{Cr} \rightarrow{ }^{18}{ }^{\circ} \mathrm{C} \rightarrow \mathrm{SmC}{ }^{*} \rightarrow{ }^{53}{ }^{\circ} \mathrm{C} \rightarrow \mathrm{SmA} \rightarrow{ }^{86}{ }^{\circ} \mathrm{C} \rightarrow \mathrm{Is}$, while the crystallization at cooling from the $\mathrm{SmC}^{*}$ phase occurs at around $7{ }^{\circ} \mathrm{C}$. So, chiral SmC* phase with low birefringence exists within a rather broad temperature range, including room temperatures.

\section{Characterization of the low birefringent FLC mixture LDN-13}

The magnitude of $\Delta n$ of the FLC LDN-13 is approximately 1.5-2 times (dependently on wavelength) lower compared with those FLCs, which were well known before as typical ones, but as was earlier thought, with quite low value $\Delta n \approx 0.15-0.16$ at $\lambda=589.3 \mathrm{~nm}$ (see, for instance, [9]). To illustrate this statement, which is one of the main results of our work, Fig. 2, $a$ shows a comparison the birefringence dispersions for the just developed FLC LDN-13 and for the long time known typical ferroelectric liquid crystal FLC-224, which is well studied and described in detail $[9,23,24]$. 
We also note that the dependence $\Delta n(\lambda)$ for the FLC LDN-13 is noticeably weaker than that for the FLC-224 (Fig. 2,a). Because of this reason, as it follows from the relation (1), the light transmittance dependence on wavelength for the FLC cell based on the FLC LDN-13 is fairly weaker than that one for the FLC-224 (Fig. 2, $b$ ). This fact means a decrease in the chromatic aberrations of the FLC cells if the birefringence lowered and the dependence $\Delta n(\lambda)$

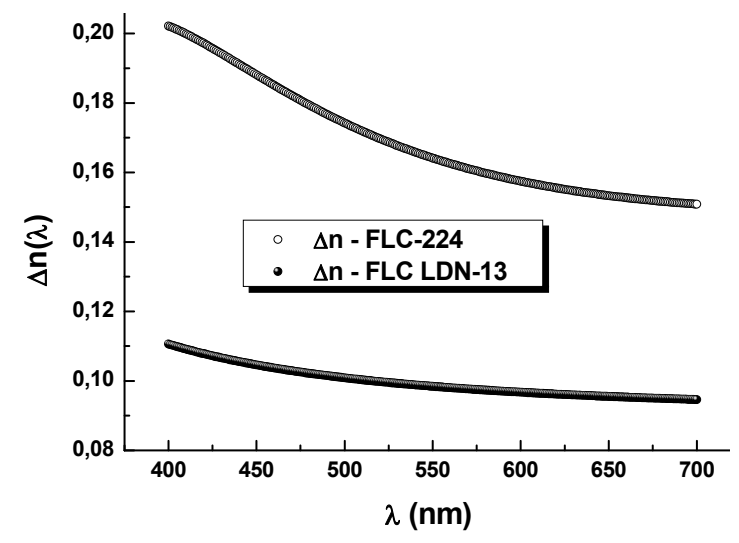

$a$ weakened. Dependence of chromatic aberrations of FLC cells on $\Delta n(\lambda)$, which is illustrated by Fig. 2, is simply a manifestation of the known from textbooks (for instance, [25]) general property of any crystaloptical structures but it is not an exceptional property of FLCs at all. Figure 2 only illustrates the opportunities achieved by the authors now for reducing the chromatic aberrations of the FLC cells, using the material science of ferroelectric liquid crystals as a tool.

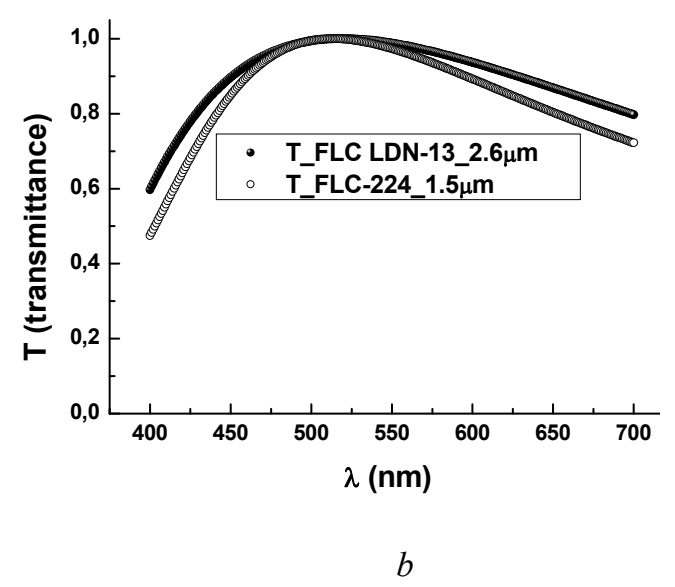

Fig. 2. $a$-Dispersions of birefringence of the FLC LDN-13 and the FLC-224 measured at T $=23{ }^{\circ} \mathrm{C} ; b-$ light transmittance spectra (normalized to the maximum ) of planar aligned FLC cells placed between crossed polarizers, with the LDN-13 layer thickness $2.6 \mu \mathrm{m}$, and the FLC-224 layer thickness $1.5 \mu \mathrm{m}$

The half-wave plate thickness $d_{\lambda / 2}$ (defined by the eq. 2) of the LDN-13 layer obviously depends on wavelength of incident light because of the birefringence dispersion (Fig. 2,a).

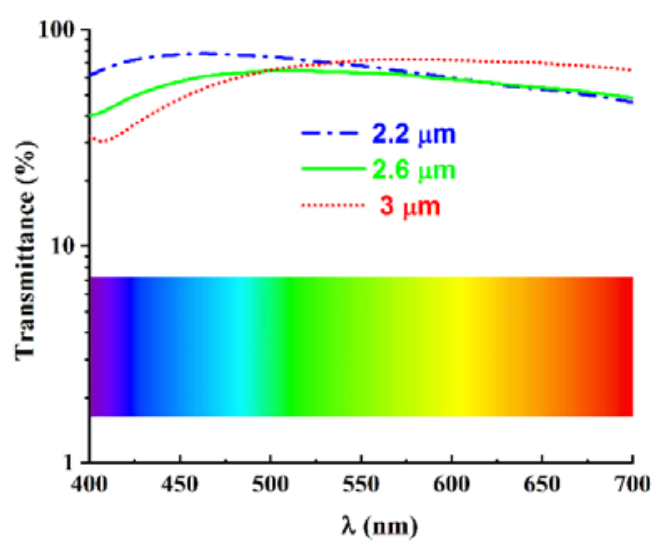

Fig. 3. Light transmittance spectra of planar aligned FLC cells placed between crossed polarizers, with the LDN-13 layer thickness $2.2 \mu \mathrm{m}, 2.6 \mu \mathrm{m}$ and $3.0 \mu \mathrm{m}$
Figure 3 allows rough estimating $d_{\lambda / 2}$ as $2.2 \mu \mathrm{m}$ for blue light, $2.6 \mu \mathrm{m}$ for green light and $3.0 \mu \mathrm{m}$ for red light.

If $d_{\lambda / 2}=2.6 \mu \mathrm{m}$ then chromatic distortion of light passing through the cell is less in comparison with $d_{\lambda / 2}=2.2 \mu \mathrm{m}$ and $d_{\lambda / 2}=3.0 \mu \mathrm{m}$, as can be seen in Fig. 3. Hence, the FLC cell with the LDN-13 layer thickness $d_{\lambda / 2}=2.6 \mu \mathrm{m}$ provides the light transmission, which is rather closest to achromatic one. Thus, increase of the FLC layer thickness with providing of almost achromatic transmittance of the FLC cells at $d_{\lambda / 2}=2.6 \mu \mathrm{m}$, is the main result of material science of low birefringent ferroelectric liquid crystals in framework of this paper. This result allows simplifying the FLC cells manufacturing technology owing to $2.6 \mu \mathrm{m}$ half-wave plate of the FLC LDN-13, whose thickness exceeds the maximal size of dust particles $(2.5 \mu \mathrm{m})$ that always exist in the air.

At the same time, minimization of chromatic distortion of the cells with the FLC-224 has been 
obtained by us, when the FLC layer thickness was about $1.5 \mu \mathrm{m}$, see Fig. $2, b$ for a comparison. Thus, the reduction in birefringence achieved by us in this work, which is illustrated in Fig. 2, $a$, made it possible to increase the thickness of the half-wave plate from $1.5 \mu \mathrm{m}$ to $2.6 \mu \mathrm{m}$ while reducing the chromatic aberrations of the FLC cell, as shown in Fig. 2, $b$.

Spontaneous polarization $\boldsymbol{P}_{\boldsymbol{s}}$ of the LDN-13 reaches $18 \mathrm{nC} / \mathrm{cm}^{2}$, as one can see in Fig. 4, $a$, while the tilt angle $\theta \approx 22.5 \mathrm{deg}$ (Fig. 4, $b$ ). Thus, the listed parameters are quite comparable with those for commercially available FLCs. At the same time, a significant disadvantage of the mixture LDN-13 is a rather high rotational viscosity $\gamma_{\varphi}$ that increases up to 2.5 Poise at $20{ }^{\circ} \mathrm{C}$ (Fig. 4, b), which leads to a significant (up to several hundred microseconds) increase in the electrooptical response time with temperature decreasing, see Fig. 4, $a$. A reason of so high rotational viscosity is that the achiral matrix of the mixture LDN-13 is composed of esters (I) - (III) but a very high $\gamma_{\varphi}$ value is an inherent property of any compounds belonging to chemical class of esters [26].

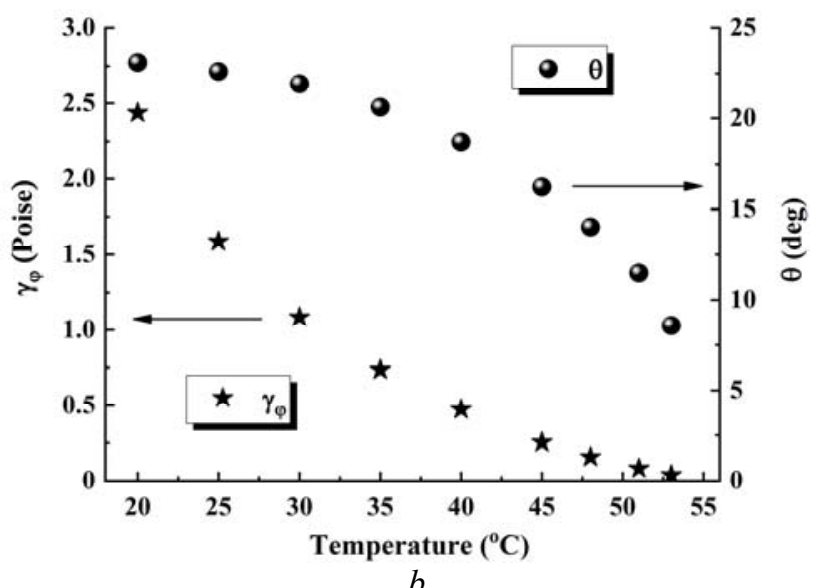

$b$

Fig. 4. Temperature dependencies: $a$ - of spontaneous polarization and electrooptical response time $\tau_{10-90}$ at applied electric field $E=5.0 \mathrm{~V} / \mu \mathrm{m} ; b-$ of the tilt angle and rotational viscosity. The measurements were performed on the FLC LDN-13

The helix pitch $p_{o}$ of the LDN-13 lies in the middle infrared range of spectrum, and therefore the helical structure can be observed in a polarizing microscope (Fig. 5) even if the FLC layer thickness is $2 \mu \mathrm{m}-5 \mu \mathrm{m}$. The helix pitch can be estimated simply from the micrograph of Fig. 5: $p_{o} \cong 2.5 \mu \mathrm{m}$, which is almost equal to the thickness of the half-wave plate. The possibility of the existence of a helical structure in the layer of a liquid crystal, whose thickness is comparable with the helix pitch, was previously proven experimentally [27] and theoretically [28]. Now we have one more confirmation of this fact but the question arises: what electro-optic effect is observed when $p_{o} \approx d$ ?

Obviously, the SSFLC effect [29] doesn't exist in this case because the condition $p_{o} \approx d$ contradicts to the definition of this effect. The multistability effect [30] was not observed also, since we have checked its absence experimentally. Most likely, the electrically suppressed helix (ESH) effect [31, 32] manifests in electrooptical response, since the electric field obviously suppresses the helical structure, which we observe in polarizing microscope (Fig. 5). At the same time, the characteristic electro-optical manifestations of this effect, described in detail in [32], are not observed in our experiments with the FLC LDN-13.

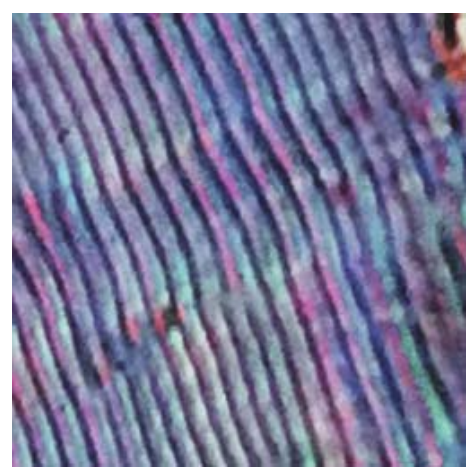

Fig. 5. Micro-photo of $5 \mu \mathrm{m}$ planar aligned LDN-13 layer placed between crossed polarizers. Size of the image is $40 \times 40 \mu \mathrm{m}$ 
Perhaps we are dealing with some special type of electro-optic behavior for the case $p_{o} \approx d$, which is not described yet. This problem will be the subject of further research in order to clarify details of the electrooptical effect classification.

\section{Conclusion}

The reduction in birefringence of ferroelectric liquid crystals (Fig. 2,a) achieved in this work due to the material science approaches made it possible to increase the thickness of the half-wave FLC plate from $1.5 \mu \mathrm{m}$ to $2.6 \mu \mathrm{m}$, at simultaneous reducing the chromatic aberrations of the FLC cell, as shown in Fig. 2, b. Some basic parameters of the elaborated ferroelectric liquid crystal material LDN-13, such as spontaneous polarization $\boldsymbol{P}_{\boldsymbol{s}}$ and the tilt angle $\theta$ are typical for commercially available ferroelectric liquid crystals, and only the rotational viscosity $\gamma_{\varphi}$ is much bigger (Fig. 4).

With this set of parameters, one can get the electrooptical response time around several hundred microseconds (Fig. 4, $a$ ), which is rather far from the best dynamics of the FLCs electrooptical response. But that is not surprising for one of the first steps in the field of materials science of the low birefringent ferroelectric liquid crystals.

\section{Acknowledgments}

The work was partially supported by the following RFBR grants: № 16-02-00441- $a$ and № 16-29-14012- ofi-m. The authors are grateful to Dr. V. Vashchenko (Hong Kong University of Science and Technology), Prof. A. Strigazzi and Prof. F. Laviano (Polytechnic University of Turin, Italy) for their help in the experimental work and useful discussions.

\section{References}

1. Bahadur B. Liquid Crystal Displays. $M C L C, 1984,109$ (1), 3-93. DOI: 10.1080/00268948408080827.

2. Petrov V.F. Liquid crystals for AMLCD and TFTPDLCD applications. Liq. Cryst., 1995, 19 (6), 729-741. DOI: $10.1080 / 02678299508031092$.

3. Kirsch P., Poetsch E. Novel Polar Liquid Crystals with Very Low Birefringence Based on trans-1,3-Dioxane Building Blocks. Adv. Mater., 1998, 10 (8), 602-608. DOI:10.1002/(SICI)1521-095(199805)10:8<602::AIDADMA602 >3.0.CO;2-8.

4. Iwashita Y., Umezu Y., Kawakami S., Takeuchi K., Kusumoto T., Takehara S., Takatsu H. Liquid Crystal
Mixtures with Low Birefringence for Active-Matrix LCD. MCLC, 2004, 411 (1), 41-48.

DOI: $10.1080 / 15421400490434559$.

5. Dabrowski R., Garbat K., Urban S., Wolinski T.R., Dziaduszek J., Ogrodnik T., Siarkowska A. Lowbirefringence liquid crystal mixtures for photonic liquid crystal fibres application. Liq. Cryst., 2017, 44 (12-13), 1-18. DOI: $10.1080 / 02678292.2017 .1360952$.

6. Swaminathan V., Panov V.P., Panarin Yu.P., Sreenilayam S.P., Vij J.K., Panov A., Rodriguez-Lojo D., Stevenson P.J., and Gorecka E. The effect of chiral doping in achiral smectic liquid crystals on the de Vries characteristics: smectic layer thickness, electro-optics and birefringence. Liq. Cryst., 2017, 45, 513-522.

DOI: $10.1080 / 02678292.2017 .1359694$.

7. Lagerwall S.T. Ferroelectric and Antiferroelectric Liquid Crystals. WILEY-VCH Verlag GmbH, Germany, 1999, Ch. 9, 241-257.

DOI: $10.1002 / 9783527613588 . \operatorname{ch} 9$.

8. Lee H., and Lee J-H. Negative dispersion of birefringence in two-dimensionally self-organized smectic liquid crystal and monomer thin film. Opt. Lett., 2014, 39 (17), 5146-5149.

DOI: $10.1364 /$ OL. 39.005146 .

9. Pozhidaev E.P. Physical properties of the smectic $\mathrm{C}^{*}$ phase of liquid crystals and the principles of creating liquid-crystal ferroelectrics with given electro-optical properties: diss. Dr. phys.-math sciences. Moscow, FIAN, 2006, 375 p.

10. Beresnev L.A., Pozhidaev E.P., Blinov L.M., Pavlyuchenko A.I., Etingen N.B. A liquid crystal ferroelectric with a record spontaneous polarization. JETP Letters, 1982, 35 (10), 938-941.

11. Pozhidaev E.P., Torgova S.I., Barbashov V.A., Minchenko M.V., Sulyanov S.N., Dorovatovskii P.V., Ostrovskii B.I., Strigazzi A. Ferroelectric C* phase induced in a nematic liquid crystal matrix by a chiral nonmesogenic dopant. Appl. Phys. Lett., 2015, 106, 062904. DOI: $10.1063 / 1.4908152$.

12. Goodby J., Demus D., Gray G., Spiess H-W., Vill V. Non-Chiral Smectic Liquid Crystals: Synthesis of NonChiral Smectic Liquid Crystals. Handbook of Liquid Crystals Set. Weinheim: Wiley-VCH Verlag GmbH, Germany, 1998, Part II, Ch. 1, 411-440.

DOI: $10.1002 / 9783527619276$.

13. LiqCryst 5.1 Available at: http://liqcryst.lci-publisher. com/en/

14. Frach R., Tschierske C., Zaschke H., Deutscher H-J. Influence of molecular structure on the liquid-crystalline properties of 1,5-dihetero-spiro[5.5] undecane- anddispiro [5.2.5.2] hexadecane derivatives. Liq. Cryst., 1989, 5 (1), 197-207.

DOI: $10.1080 / 02678298908026363$.

15. Das P., Basu S., Sinha R. K., Das U. Dipole-induced chiral smectic-C phase in a eutectic mixture of cho- 
lesterol esters. Chem. Phys. Lett., 2005, 410, 417-422. DOI: $10.1016 /$ j.cplett.2005.05.111.

16. Torgova S.I., Karamysheva L.A., Agafonova I.F., Narkevich Yu.S. Phenacylesters. A new class of liquidcrystalline compound. Liquid Crystals, 1991, 10 (6), 881-886. DOI: $10.1080 / 02678299108036463$.

17. Deutscher H-J., Laaser B., Dolling W., Schubert H. Kristallin-flüssige trans-4-n-Alkylcyclohexancarbonsäurephe-nylester. J. Prakt. Chem, 1978, 320, 191-205. DOI: $10.1002 /$ prac. 19783200204 .

18. Zhukov A.A., Pozhidaev E.P., Bakulin A.A., Babaevskiī P.G. Energy criteria for orientation of smectic $\mathrm{C}^{*}$ liquid crystals in electrooptic elements. Crystallography Reports, 2006, 51 (4), 680-684.

DOI: $10.1134 / \mathrm{S} 1063774506040237$.

19. Pozhidaev E., Friere F.C.M., Yednak C.A.R., Strigazzi A., Torgova S., Molkin V., Minchenko M. Permittivity of Chiral Smectics in the Broad Range from $0.1 \mathrm{mHz}$ to $50 \mathrm{kHz}$ : Discovery of Sub-mHz Dielectric Dispersion. Mol. Cryst. Liq. Cryst., 2011, 546, Sp. Iss. SI, 186-194. DOI: $10.1080 / 15421406.2011 .571151$.

20. Panov V., Vij J. K., Shtykov N.M. A field-reversal method for measuring the parameters of a ferroelectric liquid crystal. Liquid Crystals, 2001, 28 (4), 615-620. DOI: https://doi.org/10.1080/02678290010020175.

21. Barnik M.I., Baikalov V.A., Chigrinov V.G., and Pozhidaev E.P. Electrooptics of a thin ferroelectric smectic C* liquid crystalline layer. Mol. Cryst. Liq. Cryst., 1987, 143, 101-112.

DOI: $10.1080 / 15421408708084615$.

22. Wand M.D., Thurmes W.N., Vohra R.T., More K.M., Yoshizawa A.T., Hirai T., and Umezawa J. New Chiral Dopants Based on the 2-Fluoro-2-Methylalkoxy Tail for Use in Ferroelectric Liquid Crystal Mixtures. Mol. Cryst. Liq. Cryst., 1995, 263, 217-222.

23. Kaznacheev A.V. and Pozhidaev E.P. Anchoring energy and orientational elasticity of a ferroelectric liquid crystal. J. Exp. Theor. Phys., 2012, 114, 1043-1051.

24. Kaznacheev A., Pozhidaev E., Rudyak V., Emelyanenko A.V., and Khokhlov A. Biaxial potential of surface-stabilized ferroelectric liquid crystals. Phys. Rev. E, 2018, 97, 042703. DOI: 10.1103/PhysRevE.97.042703.
25. Born M., Wolf E. Principles of Optics. Cambridge University Press, $1999.890 \mathrm{p}$. DOI:10.1017/CBO9781139644181.024.

26. Haase W., Ganzke D., Pozhidaev E. P. Non-display applications of ferroelectric liquid crystals. Mat. Res. Soc. Symp. Proc., 1999, 599, 15-26.

DOI: $10.1557 /$ PROC-559-15.

27. Kumar M.V., Prasad S.K., Rao D.S.S, and Pozhidaev E.P. Confinement driven effects in a room temperature ferroelectric liquid crystal: X-ray, linear and non-linear dielectric investigations. Phase transitions, 2013, 86, 323-338.

DOI: $10.1080 / 01411594.2012 .678006$.

28. Kaznacheev A.V. and Pozhidaev E.P. Effect of boundary surfaces on the effective dielectric susceptibility of the helical structure of a ferroelectric liquid crystal. J. Exp. Theor. Phys., 2015, 121, 355-362. DOI: $10.7868 / \mathrm{S} 0044451015080234$.

29. Clark N.A. and Lagerwall S.T. Submicrosecond bistable electro-optic switching in liquid crystals. Appl. Phys. Lett., 1980, 36, 899-903.

DOI: https://doi.org/10.1063/1.91359.

30. Pozhidaev E.P. and Chigrinov V.G. Bistable and multistable states in ferroelectric liquid crystals. Crystallogr. Rep., 2006, 51, 1030-1040. DOI: $10.1134 /$ S1063774506060149.

31. Guo Q., Srivastava A.K., Pozhidaev E.P., Chigrinov V.G., Kwok H.S. Optimization of alignment quality of ferroelectric liquid crystals by controlling anchoring energy. Applied Physics Express, 2014 7, 021701. DOI: http://dx.doi.org/10.7567/APEX.7.021701.

32. Chigrinov V.G., Srivastava A.K., Pozhidaev E.P. Ferroelectric liquid crystals: physics and applications. Liq. Cryst. and their Appl., 2016, 16 (1), 9-21. DOI: 10.18083/LCAppl.2016.1.9.

Поступила в редакиию 16.04.2018 2. Received 16 April 2018 